ICMB21

\title{
Study on the population of airborne bacteria and antibiotic resistance from a hospital environment
}

\author{
Nur Sarah Fatihah Tamsia ${ }^{\mathrm{a}}$, Mohd Talib Latif ${ }^{\mathrm{a},}$, Murnira Othman ${ }^{\mathrm{b}}$, Farah Diba Abu Bakar ${ }^{\mathrm{c}}$, Mazrura \\ Sahani $^{\mathrm{d}}$ \\ ${ }^{a}$ Department of Earth Sciences and Environment, Faculty of Science and Technology, Universiti Kebangsaan Malaysia, 43600 Bangi, Selangor, Malaysia \\ ${ }^{b}$ Instutute foe Environment and Development (LESTARI), Universiti Kebangsaan Malaysia, 43600 Bangi, Selangor, Malaysia \\ ${ }^{c}$ Department of Biological Sciences and Biotechnology, Faculty of Science and Technology, Universiti Kebangsaan Malaysia, 43600 Bangi, Selangor, Malaysia \\ ${ }^{d}$ Center for Toxicology and Health Risk Studies, Faculty of Health Sciences, Universiti Kebangsaan Malaysia, 50300 Kuala Lumpur, Malaysia
}

\begin{abstract}
This study aims to identify the population of the airborne bacteria in a hospital and its antibiotic resistant. The airborne bacteria were collected using SKC Biostage Single Stage at three locations in a tertiary hospital in Kuala Lumpur. Temperature, relative humidity and air velocity of the sampling locations were determined using TSI VelociCalc. The screening of antibiotic resistance was conducted using disk diffusion of Kirby-Bauer method. The results show Micrococcus spp., Staphylococcus aureus, $\alpha$ and 8-Streptococcus spp., Bacillus spp., Clostridium spp. are the group of bacteria found at the sampling locations. The antibiotic resistance screening shows a wide percentage of resistance among the identified bacteria, with ampicillin as the highest percentage for the bacterial resistance.
\end{abstract}

Peer-review under the responsibility of the organizing committee of the ICMB21.

Keywords: Airborne bacteria; antibiotic resistant, hospital, physical parameter

\section{Nomenclature}

$\mathrm{CFU} / \mathrm{m}^{3} \quad$ - Colony forming unt per cubic metre

\section{Introduction/Background}

Hospitals are major places for airborne microbial contamination [1]. Based on a report from the World Health Organization, WHO [2], 8.7\% of hospital patients from 14 countries have contracted hospital-borne infections. One of the main contributors to the spread of this infection is caused by airborne pathogens that can cause cases of diseases such as tuberculosis, pneumonia, influenza and aspergillosis [3]. These airborne pathogens consist of bacteria, fungi and viruses as well as biological components. The properties of micro-sized pathogens and bound to fine dust easily enter the human body through respiration, thereby bringing harm to human health. Examples of airborne bacteria that can cause infections hospital diseases are Staphylococcus aureus, Mycobacterium tuberculosis, Legionella spp. and Acinetobacter spp. [4]. Antibiotics will often be given to patients as a method of treatment for pathogen infection. Usually, the use of these antibiotics is able to kill the pathogens that attack the patient's immune system [5]. Early detection of the presence of antibiotic-resistant bacteria in hospitals is necessary as a major step to prevent the occurrence of infections caused by antibiotic resistant bacteria.

\section{Methodology}

In this study, the population of airborne bacteria were determined at three study areas in a tertiary hospital in Kuala Lumpur, namely Respiratory Ward, Medical Clinic 1 and Emergency Department. The airborne bacterial population was sampled using active sampling and the identity of these bacteria was determined based on several bacterial identification tests. In addition, antibiotic resistance tests have also been performed using Kirby-Bauer disc absorption techniques to filter out antibiotic resistance bacteria from the bacterial population that has been identified.

\section{Results and Discussion}

The main results of this study are presented in Table 1 . The lowest bacterial population among all sampling points, at $18+12$ $\mathrm{CFU} / \mathrm{m}^{3}$ recorded at Point 2 in Respiratory Ward. Point 2 in Medical Clinic shows the highest bacterial population yield with a count of $1024+54 \mathrm{CFU} / \mathrm{m}^{3}$. The population of airborne bacteria at Point 2 Medical Clinic 1 and Point 2 of the Emergency Department has exceeded the set standards Variations in the distribution and survival of airborne bacterial populations in different points are influenced by different factors. In this study, the low air velocity as recorded in Medical Clinic Emergency Department is expected to influence the number of airborne bacteria in this area. According to Goh et al (2000) other than physical parameters, 


\section{ICMB21}

the number of patients and their activities in different sampling points also influence the number of the bacterial population in hospital.

Table 1. The bacterial population in colony forming unit $\left(\mathrm{CFU} / \mathrm{m}^{3}\right)$ and physical parameter recorded at different sampling locations.

\begin{tabular}{|c|c|c|c|c|c|}
\hline \multirow[b]{2}{*}{ Sampling Location } & \multirow{2}{*}{$\begin{array}{l}\text { Sampling } \\
\text { Point }\end{array}$} & \multicolumn{3}{|c|}{ Physical parameter } & \multirow{2}{*}{$\begin{array}{c}\text { Bacterial } \\
\text { population, } \\
\mathrm{CFU} / \mathrm{m}^{3}\end{array}$} \\
\hline & & $\begin{array}{c}\text { Temperature, } \\
{ }^{\circ} \mathrm{C}\end{array}$ & $\begin{array}{l}\text { Relative humidity, } \\
\%\end{array}$ & $\begin{array}{c}\text { Air velocity, } \\
\mathrm{m} / \mathrm{s}\end{array}$ & \\
\hline \multirow{2}{*}{ Respiratory Ward } & Point 1 & $25.4 \pm 0.8$ & $64.2 \pm 1.4$ & 0.10 & $197 \pm 26$ \\
\hline & Point 2 & $22.4 \pm 0.5$ & $64.4 \pm 0.3$ & $0.10 \pm 0.02$ & $18 \pm 12$ \\
\hline \multirow{2}{*}{ Medical Clinic 1} & Point 1 & $25.3 \pm 1.3$ & $61.1 \pm 3.2$ & 0.11 & $436 \pm 52$ \\
\hline & Point 2 & $23.7 \pm 1.0$ & $59.3+1.3$ & $0.06 \pm 0.02$ & $1024+54$ \\
\hline \multirow{2}{*}{$\begin{array}{l}\text { Emergency } \\
\text { Department }\end{array}$} & Point 1 & $26.0 \pm 0.4$ & $54.4 \pm 0.9$ & $0.04 \pm 0.01$ & $380 \pm 154$ \\
\hline & Point 2 & $26.5 \pm 0.2$ & $55.7 \pm 1.2$ & $0.08 \pm 0.01$ & $704 \pm 65$ \\
\hline
\end{tabular}

Based on Figure 1, of the 60 colonies of bacteria that have been isolated, 14 isolates have been identified as negative Gram bacteria, while another 46 isolates are positive Gram bacteria. Of the 46 positive Gram isolates, a total of 39 isolates can be identified up to the genus or species level, while 7 other positive Gram isolates could not be identified using this method. A total of 39 isolates out of 60 bacterial isolates have been identified up to the genus or species level. The identification tests conducted have identified several types of Gram positive bacteria namely $S$. aureus, Micrococcus spp., $\alpha$ - and $\beta$-Streptococcus spp., Bacillus spp. and Clostridium spp.

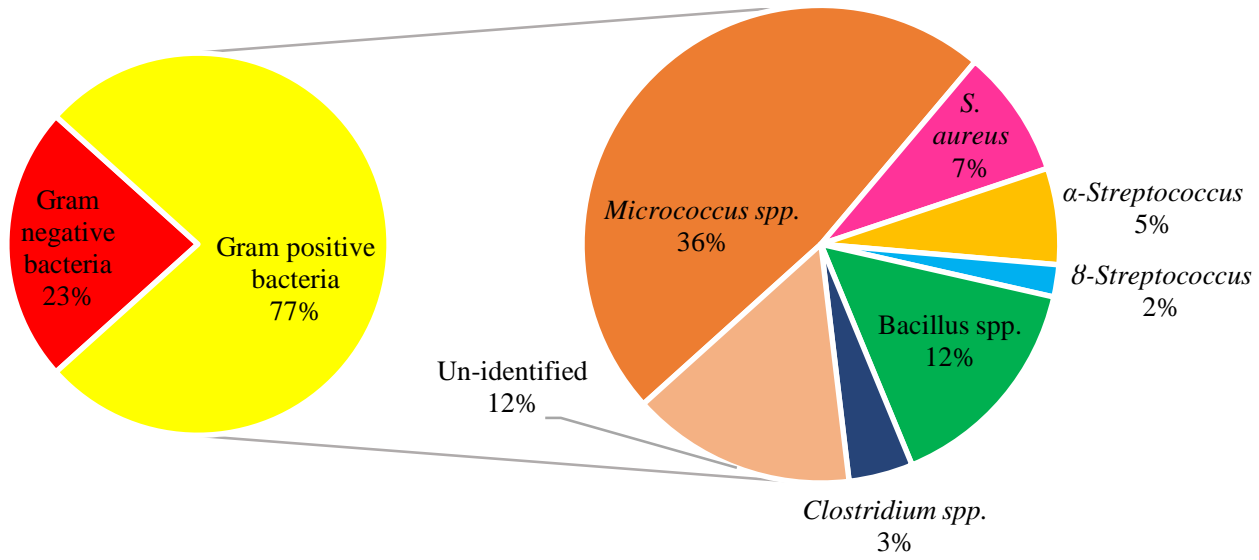

Figure 1. Identification of 60 bacterial isolates from sampling locations

Table 2 shows the use of ampicillin antibiotics has resulted in the highest percentage of antibiotic resistant bacteria for isolated strains in this study. All groups of bacteria filtered gave the highest percentage of resistance to this antibiotic. Only one isolation Micrococcus spp. and Streptococcus spp. which is sensitive to ampicillin antibiotics. This indicates the high resistance properties of bacteria by the ampicillin reaction as an agent that inhibits bacterial growth.

Table 2. Number and percentage of Gram positive bacterial isolation from hospital air samples resistant to tested antibiotics

\begin{tabular}{|c|c|c|c|c|c|c|}
\hline Bacteria & $\mathrm{n}$ & \multicolumn{5}{|c|}{ Number and percentage of antibiotic resistance isolation $(\%)$} \\
\hline S. aureus & 4 & $4(100 \%)$ & $0(0 \%)$ & $0(0 \%)$ & $2(50 \%)$ & $0(0 \%)$ \\
\hline Streptococcus spp. & 4 & $3(75 \%)$ & $1(25 \%)$ & $2(50 \%)$ & $0(0 \%)$ & $0(0 \%)$ \\
\hline Clostridium spp. & 1 & $1(100 \%)$ & $0(0 \%)$ & $0(0 \%)$ & $0(0 \%)$ & $1(100 \%)$ \\
\hline
\end{tabular}

\section{References}

[1] Wu B., Qi C., Wang L., Yang W., Zhou D., Wang M., Dong Y., Weng H., Li C., Hou X., Long X., Wang H.Chai T., (2020) Detection of microbial aerosols in hospital wards and molecular identification and dissemination of drug resistance of Escherichia coli. Environment International, 137.

[2] WHO, The world health report (2002): Reducing risks, promoting healthy life. 2002: World Health Organization.

[3] Beggs C. B., (2003) The airborne transmission of infection in hospital buildings: fact or fiction? Indoor and Built Environment, 12(1-2): p. 9-18.

[4] Gao X.-L., Shao M.-F., Wang Q., Wang L.-T., Fang W.-Y., Ouyang F.Li J., (2018) Airborne microbial communities in the atmospheric environment of urban hospitals in China. Journal of Hazardous Materials 349: 10-17.

[5] Saadoun I., Jaradat Z. W., Tayyar I. A. A., Nasser Z. E.Ababneh Q., (2015) Airborne methicillin-resistant Staphylococcus aureus in the indoor environment of King Abdullah University Hospital, Jordan. Indoor and Built Environment, 24(3): 315-323. 